\title{
HARMONISASI PENGATURAN DISIPLIN PEGAWAI NEGERI SIPIL ANTARA PERATURAN PERUNDANG-UNDANGAN DOSEN DENGAN PERATURAN PERUNDANG-UNDANGAN APARATUR SIPIL NEGARA
}

\author{
HARMONIZATION OF CIVIL SERVANTS' DISCIPLINE REGULATION \\ BETWEEN THE REGULATIONS OF LECTURER AND THE LAW ON \\ STATE CIVIL APPARATUS
}

\author{
Yusnidar1, Amrizal2 ${ }^{2}$, Mukhlis ${ }^{3}$ \\ ${ }^{1}$ Mahasiswa Program Studi Magister Hukum Universitas Malikussaleh \\ ${ }^{2,3}$ Dosen Program Studi Magister Hukum Universitas Malikussaleh \\ Email: aftasmile@gmail.com
}

\begin{abstract}
There is a difference of Lawful norm in Civil Servants' Discipline Regulation, while the Law on State Civil Apparatus shows the obligation of ASN's working hours is 7.5 hours every day, on the other hand the Regulations of Lecturer obligates the Lecturer to carry out the Tridharma Perguruan Tinggi with minimum workload 12 (twelve) Academic Credit Systems and maximum workload 16 (sixteen) Academic Credit Systems based on academic qualifications. The research aims to explain a difference lawful norm between the Regulations of Lecturer and the Law on State Civil Apparatus in implementing Civil Servants' Discipline. The results showed that the difference of Lawful norm between the Regulations of Teacher and Lecturer with the Law on State Civil Apparatus in implementing Civil Servants' Discipline is due to difference purpose of those two law, while the Regulations of Teacher and Lecturer is used to improve the quality of teachers and lecturers as professions, the Law on State Civil Apparatus is used as a legal protection for civil servants who already have professions as teachers, lecturers, prosecutors, judges and doctors.
\end{abstract}

Keywords: Harmonization, the law, civil servants, discipline

\section{Intisari}

Terjadinya perbedaan norma hukum dalam pengaturan disiplin PNS,sebagaimana diatur dalam peraturan perundang-undangan ASN dalam melaksanakan tugas profesinya wajib masuk kerja dan mentaati ketentuan jam kerja 7,5 jam setiap hari, sedangkan dalam peraturan perundang-undangan dosen dalam melaksanakan tugasnya wajib melaksanakan Tridharma Perguruan Tinggi dengan beban kerja dibebankan paling sedikit sepadan dengan 12 (dua belas) SKS dan paling banyak sepadan dengan 16 (enam belas) SKS pada setiap semester sesuai dengan kualifikasi akademik. Penelitian ini bertujuan untuk menjelaskan perbedaan norma hukum dalam pengaturan disiplin Pegawai Negeri Sipil antara peraturan perundang-undangan Dosen dengan peraturan perundang-undangan Aparatur Sipil

Suloh: Jurnal Fakultas Hukum Universitas Malikussaleh, Vol. 7, No. 2, April 2019, pp. 35-47 
Negara. Hasil penelitian ini menunjukkan bahwa terjadinya perbedaan norma hukum antara Undang-undang Guru dan Dosen dengan Undang-undang ASN dalam pengaturan disiplin PNS dikarenakan bahwa tujuan pembentukan Undangundang Guru dan Dosen adalah untuk peningkatan mutu guru dan dosen sebagai profesi yang bermartabat. Tujuan pembentukan Undang-undang ASN adalah sebagai payung hukum bagi PNS yang telah memiliki berprofesi seperti guru, dosen, jaksa, hakim dan dokter.

Kata Kunci: Harmonisasi, peraturan perundang-undangan, disiplin PNS

\section{A. Latar Belakang Masalah}

Keberadaan undang-undang dalam suatu negara mempunyai kedudukan yang strategis dan penting, baik dilihat dari konsepsi negara hukum, hierarki norma hukum, maupun dilihat dari fungsi undang-undang pada umumnya. Dalam konsepsi negara hukum, undang-undang merupakan salah satu bentuk formulasi norma hukum dalam kehidupan bernegara. Dalam pandangan Paul Scholten, bahwa hukum itu ada di dalam perundang-undangan, sehingga orang harus memberikan tempat yang tinggi kepadanya. ${ }^{1}$

Penghargaan yang tinggi terhadap peraturan perundang-undangan menjadi salah satu ciri yang dianut oleh sistem hukum kontinental. Sistem hukum kontinental mengutamakan hukum tertulis yang berupa peraturan perundangundangan yang merupakan produk legislasi sebagai sendi utama sistem hukumnya. ${ }^{2}$ Peraturan perundang-undangan adalah salah satu instrumen untuk mengatur dan mengarahkan kehidupan masyarakat menuju cita-cita yang diharapkan. ${ }^{3}$

Untuk mewujudkan cita-cita yang diharapkan, maka Pegawai Negeri Sipil sebagai unsur aparatur negara yang dituntut setia kepada Pancasila, UndangUndang Dasar Negara Republik Indonesia Tahun 1945, Negara Kesatuan Republik Indonesia dan Pemerintah bersatu padu, bermental baik, bersih, berwibawa, berdaya guna dan berhasil guna serta bersikap disiplin, jujur, adil, transparan, dan akuntabel dalam melaksanakan tugas. ${ }^{4}$

Oleh karena itu pada akhir tahun 2013, menjadi momentum yang penting bagi seluruh Pegawai Negeri Sipil di Indonesia,mengingat tanggal 19 Desember 2013 Dewan Perwakilan Rakyat Republik Indonesia bersama dengan pemerintah telah mengesahkan Rancangan Undang-Undang Aparatur Sipil Negara menjadi Undang-Undang. Undang-Undang ini telah diundangkan dengan nama Undanghlm. 91

${ }^{1}$ Satjipto Raharjo, Ilmu Hukum, Cetakan Keenam, (Bandang: PT. Citra Aditya Bakti, 2006),

${ }^{2}$ A. Rasyid Al Atok, Konsep Pembentukan Peraturan Perundang-Undangan, Edisi Revisi, (Malang: Setara Press, 2015), hlm. 1

${ }^{3} \mathrm{Ibid}, \mathrm{hlm} .2$

${ }^{4}$ Indonesia, Penjelasan Peraturan Pemerintah Tentang Disiplin PNS, PP Nomor 53 Tahun 2010 LN No. 74, TLN No. 5135.

Suloh: Jurnal Fakultas Hukum Universitas Malikussaleh, Vol. 7, No. 2, April 2019, pp. 35-47 
Undang Nomor 5 Tahun 2014 tentang Aparatur Sipil Negara pada Lembaran Negara Tahun 2014 Nomor 6, dan Tambahan Lembaran Negara Nomor 5494.

Peraturan Pemerintah Nomor 53 Tahun 2010 tentang Disiplin Pegawai Negeri Sipil sebagai peraturan pelaksanaan dari Undang-Undang Nomor 5 Tahun 2014 tentang Aparatur Sipil Negara mengatur lebih khusus dalam Pasal 3 angka 11, bahwa setiap Pegawai Negeri Sipil wajib masuk kerja dan mentaati ketentuan jam kerja.

Penjelasan dalam pasal 3 angka 11 Peraturan Pemerintah Nomor 53 Tahun 2010 tentang Disiplin Pegawai Negeri Sipil dijelaskan bahwa dengan kewajiban untuk "masuk kerja dan mentaati ketentuan jam kerja" adalah setiap pegawai negeri sipil wajib datang, melaksanakan tugas, dan pulang sesuai ketentuan jam kerja serta tidak berada ditempat umum bukan karena dinas. Apabila berhalangan hadir wajib memberitahukan kepada pejabat yang berwenang. Keterlambatan masuk kerja dan/atau pulang cepat dihitung secara kumulaltif dan dikonversi 7,5 jam sama dengan satu hari tidak masuk kerja.

Namun, penerapan Peraturan Pemerintah Nomor 53 Tahun 2010 tentang Disiplin Pegawai Negeri Sipil sebagai peraturan pelaksanaan dari UndangUndang Nomor 5 Tahun 2014 tentang Aparatur Sipil Negara tidak dapat terlaksana secara efektif bagi Pegawai Negeri Sipil yang berprofesi Dosen, sebagaimana hasil penelitian yang dilakukan oleh Heny Yuningrum, yang berjudul "Dampak Ekonomi dari Penerapan Sistem Biometrik di Kalangan PNS Perguruan Tinggi Islam", menyatakan bahwa pemberlakuan sistem biometrik (finger print) tidak mempengaruhi pegawai khususnya dosen untuk disiplin absen kerja 7,5 jam perhari, disebabkan dosen selain tugas mengajar juga mempunyai tugas tambahan lainnya di luar mengajar diantaranya penelitian dan pengabdian kepada masyarakat yang terkadang mewajibkan dosen untuk tidak bisa absen ke kantor, namun penggunaan finger print lebih dominan kepada pembayaran uang makan dan tunjangan kinerja. ${ }^{6}$

Penelitian yang dilakukan oleh Syahir Badrudin, yang berjudul Efektivitas Pelaksanaan Finger Print di IAIN Raden Patah Palembang, menyatakan bahwa finger print sebagai alat kontrol kinerja belum dapat diukur secara pasti karena belum terjadi perubahan yang signifikan pada peningkatan kinerja. Artinya bahwa finger print masih dijadikan sebagai alat untuk membuktikan bahwa pegawai hadir datang dan pulang tepat waktu, sedangkan pada saat jam kerja masih terjadi peristiwa sebagaimana sebelum alat ini diberlakukan. ${ }^{7}$

Kedua penelitian tersebut diatas dapatlah diketahui bahwa penerapan Peraturan Pemerintah Nomor 53 Tahun 2010 tentang Disipliin Pegawai Negeri Sipil sebagai pedoman dalam pelaksanaan disiplin Pegawai Negeri Sipil secara

\footnotetext{
${ }^{5}$ Akhmad Aulawi, Penerapan Sistem Merit dalam Manajeman ASN dan Netralitas ASN dari Unsur Politik dalam Undang-Undang ASN, (Jurnal :Rechvinding).

${ }^{6}$ Heny Yuningrum, Dampak Ekonomi dari Penerapan Sistem Biometrik di Kalangan PNS Perguruan Tinggi Islam, (Jurnal Economica, Volume V Edisi 1 Mei 2014).

${ }^{7}$ Syahir Badruddin, Efektivitas Pelaksanaan Fingerprint di IAIN Raden Patah Palembang, Jurnal Wardah No. XXVII Juni 2014.

Suloh: Jurnal Fakultas Hukum Universitas Malikussaleh, Vol. 7, No. 2, April 2019, pp. 35-47
} 
umum dapat diberlakukan, namun khusus untuk Pegawai Negeri Sipil yang berprofesi Dosen tidaklah berpengaruh sama sekali. Dosen sebagi pegawai aparatur sipil negara dalam jabatan fungsional keahlian ${ }^{8}$ adalah pendidik profesional dan ilmuwan dengan tugas utama mentransformasikan, mengembangkan, dan menyebarluaskan ilmu pengetahuan, teknologi, dan seni melalui pendidikan, penelitian, dan pengabdian kepada masyarakat. ${ }^{9}$

Kedudukan dosen sebagai tenaga profesional bertujuan untuk melaksanakan sistem pendidikan nasional dalam mewujudkan visi perguruan tinggi yaitu menyelenggarakan pendidikan, penelitian, dan pengabdian kepada masyarakat yang disebut dengan Tridharma Perguruan Tinggi dengan beban kerja sebagaimana diatur dalam Pasal 72 Undang-Undang Nomor 14 Tahun 2005 tentang Guru dan Dosen berbunyi sebagai berikut:

(1) Beban kerja dosen mencakup kegiatan pokok yaitu merencanakan pembelajaran, melaksanakan proses pembelajaran, melakukan evaluasi pembelajaran, membimbing dan melatih, melakukan penelitian, melakukan tugas tambahan, serta melakukan pengabdian kepada masyarakat.

(2) Beban kerja sebagaimana yang dimaksud pada ayat (1) sekurang-kurangnya sepadan dengan 12 (dua belas) satuan kredit semester dan sebanyakbanyaknya 16 (enam belas) satuan kredit semester.

(3) Ketentuan lebih lanjut mengenai beban kerja dosen sebagaimana dimaksud pada ayat (1) dan ayat (2) diatur oleh setiap satuan pendidikan tinggi sesuai dengan peraturan perundang-undangan.

Lebih khusus lagi mengenai beban kerja dosen diatur dalam Peraturan Pemerintah Nomor 37 Tahun 2009 tentang Dosen sebagai peraturan pelaksanaan dari Undang-Undang Nomor 14 Tahun 2005 tentang Guru dan Dosen, Pasal 8 huruf $\mathrm{b}$ melaksanakan tridharma perguruan tinggi dengan beban kerja paling sedikit sepadan dengan 12 (dua belas) SKS dan paling banyak 16 (enam belas) SKS pada setiap semester sesuai dengan kualifikasi akademiiknya dengan ketentuan:

1) Beban kerja pendidikan dan penelitian paling sedikit sepadan dengan 9 (sembilan) SKS yang dilaksanakan di perguruan tinggi yang bersangkutan; dan

2) Beban kerja pengabdian kepada masyarakat dapat dilaksanakan melalui kegiatan pengabdian kepada masyarakat yang diselenggarakan oleh perguruan tinggi yang bersangkutan atau melalui lembaga lain;

Berdasarkan peraturan perundang-undangan tentang dosen, bahwa tugas dosen sebagai tenaga aparatur sipil negara secara profesional diwajibkan melaksanakan tugas untuk mewujudkan visi perguruan tinggi yaitu menyelenggarakan pendidikan, penelitian, dan pengabdian kepada masyarakat

\footnotetext{
${ }^{8}$ Indonesia, Lampiran Keputusan Presiden RI tentang Rumpun Jabatan Fungsional Pegawai Negeri Sipil, Kepres RI Nomor 87 Tahun 1999.

${ }^{9}$ Indonesia, Undang-Undang Guru dan Dosen, Undang-Undang Nomor 14 Tahun 2005, LN No. 157, TLN No. 4586, Ps.1 Angka 2.
}

Suloh: Jurnal Fakultas Hukum Universitas Malikussaleh, Vol. 7, No. 2, April 2019, pp. 35-47 
yang disebut dengan Tridharma Perguruan Tinggi dengan beban kerja paling sedikit sepadan dengan 12 (dua belas) SKS dan paling banyak 16 (enam belas) SKS pada setiap semester sesuai dengan kualifikasi akademiknya yang apabila tidak dilaksanakan dikenakan hukuman sanksi dari berupa teguran lisan hingga pemberhentian tidak dengan hormat.

Berdasarkan kedua peraturan perundang-undangan tersebut di atas terjadi perbedaan norma hukum dalam penerapan disiplin Pegawai Negeri Sipil, hal ini sebagaimana diatur dalam peraturan perundang-undangan Aparatur Sipil Negara bahwa dalam melaksanakan tugas profesinya wajib masuk kerja dan mentaati ketentuan jam kerja 7,5 jam setiap hari. Sedangkan dalam peraturan perundangundangan dosen, dalam melaksanakan tugasnya wajib melaksanakan Tridharma Perguruan Tinggi dengan beban kerja dibebankan paling sedikit sepadan dengan 12 (dua belas) SKS dan paling banyak sepadan dengan 16 (enam belas) SKS pada setiap semester sesuai dengan kualifikasi akademik. Oleh karena itu, penulis tertarik untuk mengkaji dan menganalisis mengenai "Harmonisasi Pengaturan Disiplin Pegawai Negeri Sipil antara Peraturan Perundang-Undangan Dosen dengan Peraturan Perundang-Undangan Aparatur Sipil Negara".

Berdasarkan latar belakang masalah diatas, maka dapat dirumuskan bahwa pertanyaan yang akandi jawab dalam penelitian ini adalah mengapa terjadi perbedaan norma hukum dalam pengaturan disiplin Pegawai Negeri Sipil antara Peraturan Perundang-Undangan Dosen dengan Peraturan Perundang-Undangan Aparatur Sipil Negara?

Berdasarkan pertanyaan penelitian diatas maka yang menjadi tujuan dalam penelitian inia dalah untuk menjelaskan adanya perbedaan norma hukum dalam penerapan disiplin Pegawai Negeri Sipil antara Peraturan Perundang-Undangan Dosen dengan Peraturan Perundang-Undangan Aparatur Sipil Negara.

Penelitian ini diharapkan dapat dijadikan bahan masukan (input) kepada instansi yang berwenang dalam mengambil kebijakan (policy) untuk memperbaiki dan menyempurnakan kekurangan yang ada, khususnya yang berkaitan dengan penerapan disiplin Pegawai Negeri Sipil khususnya yang berprofesi dosen.

\section{B. Metode Penelitian}

Penelitian ini adalah tipe penelitian yuridis normatif, hal ini sebagai konsekuensi pemilihan topik yang akan dikaji. Adapun maksud dari tipe penelitian tersebut akan dikonsentrasikan pada kaidah-kaidah atau norma-norma yang ada di dalam hukum positif atau hukum yang sedang berlaku pada saat sekarang dan yang ada di Indonesia. Dengan demikian terjadilah suatu persesuaian kehendak dan adanya korelasi antara segala permasalahan yang terdapat pada rumusan masalah yang telah ditetapkan menyangkut disiplin pegawai aparatur sipil negara secara umum dan pegawai aparatur sipil negara dalam profesi dosen khususnya.

Adapun penelitian hukum ini dilakukan untuk mengkaji dan menganalisa pengaturan disiplin Pegawai Negeri Sipil berdasarkan Peraturan PerundangUndangan Dosen dan Peraturan Perundang-Undangan Aparatur Sipil Negara, 
sedangkan hasil yang akan dicapai dari sebuah penelitian hukum tersebut adalah preskriptif mengenai bagaimana penerapan disiplin pegawai aparatur disiplin negara berprofesi dosen yang mempengaruhi isu hukum yang diajukan.

Pendekatan masalah haruslah sesuai dengan tipe penelitian yang telah ditetapkan. Sehubungan dengan tipe penelitian yuridis normatif maka pendekatan masalah yang paling tepat adalah pendekatan perundang-undangan (Statute Approach). Pendekatan ini dimaksudkan melakukan pengkajian hierarki dan asasasas dalam peraturan perundang-undangan ${ }^{10}$ dengan pokok bahasan, yaitu dengan menganalisa aturan hukum terkait antara Peraturan Perundang-UndanganDosen dengan Peraturan Perundang-Undangan Aparatur Sipil Negara.

Untuk memecahkan isu hukum dan sekaligus memberikan preskripsi mengenai apa yang seyogyanya, diperlukan sumber-sumber penelitian. Sumbersumber penelitian hukum dapat dibedakan menjadi sumber-sumber penelitian yang berupa bahan-bahan hukum primer dan sekunder. ${ }^{11}$ Adapun sumber-sumber bahan hukum dalam penelitian ini sebagai berikut:

a. Bahan hukum primer, maksudnya adalah bahan hukum yang diperoleh dari peraturan perundang-undangan yang berlaku dan tentunya yang berhubungan dengan permasalahan yang dikaji, diantaranya adalah:

1) Undang-Undang Dasar Negara Republik Indonesia Tahun 1945;

2) Undang-Undang Nomor 20 Tahun 2003 tentang Sistem Pendidikan Nasional;

3) Undang-Undang Nomor 14 Tahun 2005 tentang Guru dan Dosen;

4) Undang-Undang Nomor 5 Tahun 2014 tentang Aparatur Sipil Negara;

5) Peraturan Pemerintah Nomor 37 Tahun 2009 tentang Dosen;

6) Peraturan Pemerintah Nomor 53 Tahun 2010 tentang Disiplin Pegawai Negeri Sipil

b. Bahan hukum sekunder, yaitu bahan-bahan hukum yang diperoleh dari hasil membaca buku-buku hukum, tesis, disertasi hukum serta jurnal-jurnal hukum yang ada kaitannya dengan permasalahan yang akan dibahas. Untuk mendapatkan data-data secara riil sebagai pengetahuan dasar yang dapat mendukung dalam pembuatan usulan penelitian yang berbentuk karya ilmiah ini. Bahan hukum sekunder meliputi antara lain:

1) Hasil penelitian/kajian mengenai disiplin pegawai aparatus sipil negara

2) Jurnal-jurnal hukum tentang asas-asas hukum dalam penerapan peraturan perundang-undangan.

Bahan-bahan hukum yang diperoleh dari bahan hukum primer dan bahan hukum sekunder dipelajari atau dikaji serta diidentifikasi. Hal ini dapat dilakukan dengan cara studi kepustakaan, selanjutnya dicari yang relevan dengan pokok permasalahan yang ada, kemudian disusun atau ditata dan dibuat secara sistematis agar terciptanya suatu karya ilmiah.

${ }^{10}$ Peter Mahmud Marzuki, Penelitian Hukum, Edisi Revisi, (Jakarta: Prenada Media Group, 2011), hlm. 136.

${ }^{11}$ Ibid., hlm. 181.

Suloh: Jurnal Fakultas Hukum Universitas Malikussaleh, Vol. 7, No. 2, April 2019, pp. 35-47 
Setelah bahan hukum terkumpul, baik bahan hukum primer maupun bahan hukum sekunder maka selanjutnya dilakukan analisis. Langkah-langkah analisis dalam penelitian hukum normatif ini adalah sesuai dengan pendapat Peter Mahmud Marzuki dalam bukunya yang berjudul "Penelitian Hukum" antara lain sebagai berikut:

1) Mengidentifikasi fakta hukum yang mengeliminasi penjelasan substansi pasal yang tidak relevan.

2) Mengumpulkan bahan-bahan hukum dan non hukum yang relevan dengan isu hukum.

3) Menelaah isu hukum berdasarkan bahan hukum yang telah dikumpulkan;

4) Menarik kesimpulan dalam bentuk argumentasi sesuai dengan isu hukum;

5) Memberikan preskripsi berdasarkan argumentasi yang telah dibangun. ${ }^{12}$

\section{Hasil Temuan dan Diskusi}

Norma hukum dalam suatu undang-undang merupakan sebagai perintah (gebod) dan larangan (verbod) yang apabila dilanggar dikenakan sanksi hukuman. Adapun norma hukum dalam Peraturan Perundang-Undangan Dosen pengaturan disiplin PNS diatur dalam Undang-Undang Nomor 14 Tahun 2005 tentang Guru dan Dosen Pasal 60 sebagai berikut:

a. Melaksanakan pendidikan, penelitian, dan pengabdian kepada masyarakat;

b. Merencanakan, melaksanakan proses pembelajaran, serta menilai dan mengevaluasi hasil pembelajaran;

c. Meningkatkan dan mengembangkan kualifikasi akademik dan kompetensi secara berkelanjutan sejalan dengan perkembangan ilmu pengetahuan, teknologi, dan seni;

d. Bertindak objektif dan tidak diskriminatif atas dasar pertimbangan jenis kelamin, agama, suku, ras, kondisi fisik tertentu, atau latar belakang sosioekonomi peserta didik dalam pembelajaran;

e. Menjunjung tinggi peraturan perundang-undangan, hukum, dan kode etik, serta nilai-nilai agama dan etika; dan

f. Memelihara dan memupuk persatuan dan kesatuan bangsa.

Selanjutnya Pasal 78 Undang-Undang Guru dan Dosen ayat (1) dan (2) berbunyi sebagai berikut:

1) Dosen yang diangkat oleh Pemerintah yang tidak melaksanakan kewajiban sebagaimana dimaksud dalam Pasal 60 dikenai sanksi sesuai dengan peraturan perundang-undangan.

2) Sanksi sebagaimana dimaksud ayat (1) berupa:
a. Teguran;
b. Peringatan tertulis;
c. Penundaan pemberian hak dosen;
d. Penurunan pangkat dan jabatan akademik;
e. Pemberhentian dengan hormat; atau
f. Pemberhentian tidak dengan hormat.

${ }^{12}$ Ibid, hlm. 213.

Suloh: Jurnal Fakultas Hukum Universitas Malikussaleh, Vol. 7, No. 2, April 2019, pp. 35-47 
Kedudukan dosen sebagai tenaga profesional bertujuan untuk melaksanakan sistem pendidikan nasional dalam mewujudkan visi perguruan tinggi yaitu menyelenggarakan pendidikan, penelitian, dan pengabdian kepada masyarakat yang disebut dengan tridharma perguruan tinggi dengan beban kerja sebagaimana diatur dalam Pasal 72 Undang-Undang Guru dan Dosen berbunyi sebagai berikut:

1) Beban kerja dosen mencakup kegiatan pokok yaitu merencanakan pembelajaran, melaksanakan proses pembelajaran, melakukan evaluasi pembelajaran, membimbing dan melatih, melakukan penelitian, melakukan tugas tambahan, serta melakukan pengabdian kepada masyarakat.

2) Beban kerja sebagaimana yang dimaksud pada ayat (1) sekurang-kurangnya sepadan dengan 12 (dua belas) satuan kredit semester dan sebanyakbanyaknya 16 (enam belas) satuan kredit semester.

3) Ketentuan lebih lanjut mengenai beban kerja dosen sebagaimana dimaksud pada ayat (1) dan ayat (2) diatur oleh setiap satuan pendidikan tinggi sesuai dengan peraturan perundang-undangan.

Lebih khusus lagi mengenai beban kerja dosen diatur dalam Peraturan Pemerintah Nomor 37 Tahun 2009 tentang Dosen sebagai peraturan pelaksanaan dari Undang-Undang Nomor 14 Tahun 2005 tentang Guru dan Dosen, Pasal 8 huruf $\mathrm{b}$ melaksanakan Tridharma Perguruan Tinggi dengan beban kerja paling sedikit sepadan dengan 12 (dua belas) SKS dan paling banyak 16 (enam belas) SKS pada setiap semester sesuai dengan kualifikasi akademiiknya dengan ketentuan:

1) Beban kerja pendidikan dan penelitian paling sedikit sepadan dengan 9 (sembilan) SKS yang dilaksanakan di perguruan tinggi yang bersangkutan; dan

2) Beban kerja pengabdian kepada masyarakat dapat dilaksanakan melalui kegiatan pengabdian kepada masyarakat yang diselenggarakan oleh perguruan tinggi yang bersangkutan atau melalui lembaga lain;

Norma hukum dalam Undang-Undang Aparatur Sipil Negara yang mengatur tentang disiplin PNS sebagaimana yang tersebut dalam Pasal 86 Undang-Undang Aparatur Sipil Negara sebagai berikut:

1) Untuk menjamin terpeliharanya tata tertib dalam kelancaran pelaksanaan tugas, PNS wajib mematuhi disiplin PNS.

2) Instansi Pemerintah wajib melaksanakan penegakan disiplin terhadap PNS serta melaksanakan berbagai upaya peningkatan disiplin.

3) PNS yang melakukan pelanggaran disiplin dijatuhi hukuman disiplin.

4) Ketentuan lebih lanjut mengenai disiplin sebagaimana dimaksud pada ayat (1), ayat (2), dan ayat (3) diatur dengan Peraturan Pemerintah.

Untuk menindaklanjuti ketentuan dari Undang-Undang Aparatur Sipil Negara tersebut, maka pemerintah membuat kebijakan lebih khusus yang diatur dalam Peraturan Pemerintah Nomor 53 Tahun 2010 Pasal 3 angka 11, bahwa setiap PNS wajib masuk kerja dan mentaati ketentuan jam kerja.

Penjelasan dalam Pasal 3 angka 11 Peraturan Pemerintah 53 Tahun 2010 dijelaskan bahwa dengan kewajiban untuk "masuk kerja dan mentaati ketentuan

Suloh: Jurnal Fakultas Hukum Universitas Malikussaleh, Vol. 7, No. 2, April 2019, pp. 35-47 
jam kerja" adalah setiap pegawai negeri sipil wajib datang, melaksanakan tugas, dan pulang sesuai ketentuan jam kerja serta tidak berada ditempat umum bukan karena dinas. Apabila berhalangan hadir wajib memberitahukan kepada pejabat yang berwenang. Keterlambatan masuk kerja dan/atau pulang cepat dihitung secara kumulaltif dan dikonversi 7,5 jam sama dengan satu hari tidak masuk kerja".

Dari kedua peraturan perundang-undangan tersebut terjadi perbedaan norma hukum dalam pengaturan disiplin PNS antara beban kerja yang diatur dalam Peraturan Perundang-Undangan Dosen dengan jam kerja yang diatur dalam Peraturan Perundang-Undangan Aparatur Sipil Negara.

Undang-undang adalah salah satu sumber hukum yang memiliki kekuatan mengikat bagi semua orang dalam suatu negara. Ketika undang-undang telah disahkan, maka undang-undang dinyatakan berlaku dan semua warga negara dianggap telah mengetahui keberadaan undang-undang tersebut.

Sifat norma hukum yang diatur dalam undang-undang berimplikasi pada jenis maupun institusi atau pejabat yang berwenang membentuknya. Termasuk pula berimplikasi terhadap penjabaran norma dari norma yang abstrak menjadi norma yang konkret berdasarkan kewenangan hingga suatu bentuk undangundang lahir. Sebagaimana diketahui bahwa kewenangan yang dimiliki institusi atau pejabat dalam membentuk undang-undang diperoleh melalui atribusi ataupun delegasi kewenangan.

Pada dasarnya membentuk undang-undang merupakan kekuasaan yang melekat pada Dewan Perwakilan Rakyat (disingkat DPR), selain kekuasaan pengawasan dan anggaran. Wewenang pembentukan undang-undang ini diwujudkan kedalam fungsi legislasi DPR. Kekuasaan membentuk undangundang pada DPR merupakan wewenang atribusi yang diberikan oleh UndangUndang Dasar Negara Republik Indonesi Tahun 1945 Pasal 20 ayat (1) yang menyatakan bahwa: "Dewan Perwakilan Rakyat memegang kekuasaan membentuk undang-undang".

Namun demikian, Presiden juga memiliki kekuasaan membentuk undangundang dalam bentuk hak mengajukan Rancangan Undang-Undang kepada DPR dan sekaligus tugas untuk mengesahkan Rancangan Undang-Undang yang telah disetujui bersama untuk menjadi undang-undang yang juga merupakan atribusi yang diberikan oleh Undang-Undang Dasar Negara Republik Indonesia Tahun 1945 Pasal 5 ayat (1) berbunyi: "Presiden berhak mengajukan rancangan undangundang kepada Dewan Perwakilan Rakyat" dan Pasal 20 ayat (4) berbunyi: "Presiden mengesahkan rancangan undang-undang yang telah disetujui bersama untuk menjadi undang-undang".

Rancangan Undang-Undang yang diajukan oleh Presiden disiapkan oleh Menteri atau pimpinan lembaga pemerintah non departemen, sesuai dengan lingkup tugas dan tanggung jawabnya. Rancangan Undang-Undang yang telah disiapkan diajukan dengan Surat Presiden (Supres) kepada Pimpinan DPR. Dalam Supres ditegaskan antara lain tentang Menteri yang ditugasi mewakili Presiden dalam melakukan pembahasan Rancangan Undang-Undang di DPR. Dalam

Suloh: Jurnal Fakultas Hukum Universitas Malikussaleh, Vol. 7, No. 2, April 2019, pp. 35-47 
jangka waktu paling lambat 60 (enam puluh) hari sejak Supres diterima, DPR harus mulai membahas Rancangan Undang-Undang. Untuk keperluan pembahasan Rancangan Undang-Undang di DPR, Menteri dan atau pimpinan lembaga pemrakarsa memperbanyak naskah Rancangan Undang-Undang tersebut dalam jumlah yang diperlukan.

Rancangan Undang-Undang yang berasal dari DPR (usul inisiatif DPR) diusulkan oleh DPR, yang disampaikan kepada Presiden dengan Surat Pimpinan DPR (Surpim DPR). Presiden menugasi menteri yang mewakili untuk membahas Rancangan Undang-Undang bersama DPR dalalm jangka waktu paling lambat 60 (enam puluh) hari sejak Surpim DPR diterima. Menteri yang ditunjuk Presiden selanjutnya mengkoordinasikan persiapan pembahasan dengan menteri yang tugas dan tanggung jawabnya di bidang peraturan perundang-undangan. Untuk keperluan pembahsan, Rancangan Undang-Undang inisiatif DPR ini diperbanyak (digandakan) oleh Sekretariat DPR dalam jumlah yang diperlukan.

Adapun tahapan pembentukan undang-undang, dimulai dari tahap persiapan dan pembahasan. Rancangan Undang-Undang Guru dan Dosen merupakan inisiatif DPR, dalam rangka meningkatkan citra, harkat dan martabat, profesionalisme, kesejahteraan, rasa aman dalam pelaksanaan tugas, serta perlakuan adil bagi semua guru dan dosen. Kedudukan guru dan dosen sebagai tenaga profesional bertujuan untuk melaksanakan sistem pendidikan nasional dan mewujudkan tujuan pendidikan nasional, yakni berkembangnya potensi peserta didik agar menjadi manusia yang beriman dan bertakwa kepada Tuhan Yang Maha Esa, berkahlak mulia, sehat, berilmu, cakap, kreatif, mandiri, serta menjadi warga negara yang demokratis dan bertanggungjawab. Pengakuan kedudukan guru dan dosen sebagai tenaga profesional merupakan bagian dari pembaharuan sistem pendidikan nasional yang pelaksanaannya memperhatikan berbagai ketentuan peraturan perundang-undangan di bidang pendidikan, kepegawaian, ketenagakerjaan, keuangan, pemerintah daerah. ${ }^{13}$

Proses pembahasan Rancangan Undang-Undang Guru dan Dosen, secara efektif dilakukan selama 3 (tiga) bulan, dengan melibatkan seluruh stakeholders pendidikan melalui Rapat Dengar Pendapat Umum (RDP), audiensi, konsultasi publik, dan juga rapat konsultasi dengan Panitia Ad Hoc (PAH) III DPD RI. Dari hasil pertemuan tersebut, kemudian dijadikan dasar untuk merumuskan Draft Rancangan Undang-Undang Guru dan Dosen secara komperehensif dan paripurna. Adapun rumusan tersbut mencakup 8 (delapan) bab dan 84 (delapan puluh empat) pasal yang terdiri dari: ${ }^{14}$

Ketentuan Umum

bab I Bab ini memuat tentang batasan pengertian dan istilah-istilah yang digunakan dalam Undang-Undang ini

Kedudukan, Fungsi dan Tujuan

bab II Bab ini mengatur tentang kedudukan, fungsi dan tujuan guru

${ }^{13}$ Risalah DPR-RI, Rancangan Undang-Undang Guru dan Dosen, tanggal 6 Desember 2015, hlm. 21.

${ }^{14}$ Ibid.,hlm. 21-23.

Suloh: Jurnal Fakultas Hukum Universitas Malikussaleh, Vol. 7, No. 2, April 2019, pp. 35-47 
dan dosen, sebagai tenaga pendidik profesional.

Prinsip Profesionalitas

bab III Bab ini memuat tentang prinsip-prinsip profesionalitas guru dan dosen dan pemberdayaan profesi guru dan dosen.

bab IV

Guru

Bab ini memuat tentang kualifikasi, kompetensi, dan sertifikasi guru, hak dan kewajiban guru, wajib kerja dan ikatan dinas, pengangkatan, penempatan, pemindahan dan pemberhentian, serta pembinaan dan pengembangan, penghargaan, perlindungan, cuti, organisasi profesi dan kode etik guru.

Bab V : Dosen

Bab ini memuat tentang kualifikasi, kompetensi dan sertifikasi dosen, hak dan kewajiban dosen, wajib kerja dan ikatan dinas, pengangkatan, penempatan, pemindahan dan pemberhentian, serta pembinaan dan pengembangan, penghargaan, perllindungan dan cuti bagi dosen.

Bab VI : Sanksi

Bab ini memuat tentang sanksi yang diberikan kepada guru dan dosen yang diangkat oleh Pemerintah, pemerintah daerah dan satuan pendidikan yang diselenggarakan oleh masyarakat, yang tidak menjalankan kewajibannya.

Bab VII : Ketentuan Peralihan

$\mathrm{Bab}$ ini memuat tentang penyesuaian dengan peraturan perundang-undangan yang sudah ada, agar tidak timbul permasalahan antara Undang-Undang Guru dan Dosen dengan peraturan perundang-undangan lainnya.

Bab VIII : Ketentuan Penutup

Bab ini menunjukkan organ atau alat perlengkapan yang melaksanakan Undang-Undang Guru dan Dosen ini.

Rumusan tersebut akhirnya disepakati dan disetujui untuk disahkan menjadi Undang-Undang Nomor 14 Tahun 2005 tentang Guru dan Dosen, walaupun terdapat sedikit perbedaan dari beberapa fraksi, namun pada dasarnya seluruh fraksi yang ada di DPR dan juga Pemerintah dalam hal ini didelegasikan kepada Menteri Pendidikan dan Kebudayaan (sekarang Menteri Riset, Teknologi dan Perguruan Tinggi disingkat Menristek Dikti) menyetujui untuk disahkan menjadi undang-undang.

Disahkannya Rancangan Undang-Undang Guru dan Dosen menjadi Undang-Undang Nomor 14 Tahun 2005 dengan tujuan untuk memberikan payung hukum bagi pemberdayaan, peningkatan harkat dan martabat, dan perlindungan terhadap profesi guru dan dosen guna mempercepat tercapainya tujuan pembangunan nasional di bidang pendidikan.

Suloh: Jurnal Fakultas Hukum Universitas Malikussaleh, Vol. 7, No. 2, April 2019， pp. 35-47 
Mencerdaskan kehidupan bangsa merupakan salah satu komitmen bangsa Indonesia yang dituangkan dalam Pembukaan Undang-Undang Dasar Negara Kesatuan Republik Indonesia Tahun 1945. Dalam komitmen tersebut tersirat amanat akan pentingnya sistem pendidikan nasional beserta dengan komponenkomponenya. Salah satu dari komponen sistem pendidikan nasional adalah dosen yang mempunyai peran strategis dalam penyelenggaraan pendidikan. Kualitas manusia yang dibutuhkan oleh bangsa Indonesia pada masa yang akan datang adalah manusia yang mampu menghadapi persaingan yang semakin ketat dengan bangsa lain di dunia. Kualitas manusia Indonesia tersebut hanya bisa dihasilkan melalui penyelenggaraan pendidikan yang bermutu. Pasal 39 ayat (2) UndangUndang Nomor 20 Tahun 2003 tentang Sistem Pendidikan Nasional menyatakan bahwa pendidik merupakan tenaga profesional. Kedudukan dosen sebagai tenaga profesional mempunyai visi terwujudnya penyelenggaraan pembelajaran sesuai dengan prinsip profesionalitas untuk memenuhi hak yang sama bagi setiap warga negara dalam memperoleh pendidikan yang bermutu. ${ }^{15}$

Adapun yang melatar belakangi pembentukan Undang-Undang Nomor 14 Tahun 2005 tentang Guru dan Dosen sebagaimana dalam Rapat Paripurna DPR RI pada tanggal 6 Desember 2005 tentang pembahasan Rancangan UndangUndang Guru dan Dosen menjadi undang-undang dalam rangka:

I. Untuk meningkatkan dan mengembangkan kompetensi dan profesionalitas dosen;

II. Melindungi profesi dosen berikut kesejahteraannya;

III. Mengakui potensi strategis dari organisasi profesi dosen.

Secara yuridis pembentukan Undang-Undang Guru dan Dosen merupakan legitimasi dari Undang-Undang Sistem Pendidikan Nasional Pasal 39 ayat (2) dan merupakan penjabaran norma hukum dari Undang-Undang Dasar Negara Kesatuan Republik Indonesia Tahun 1945 Pasal 31 ayat (3).

Pasal 31 ayat (3) UUD NRI Tahun 1945 menyatakan bahwa: "Pemerintah mengusahakan dan menyelenggarakan satu sistem pendidikan nasional, yang meningkatkan keimanan dan ketakwaan serta akhlak mulia dalam rangka mencerdaskan kehidupan bangsa, yang diatur dengan undang-undang".

Selanjutnya Pasal 39 ayat (2) Undan-Undang Sistem Pendidikan Nasional menyatakan bahwa: "Pendidik merupakan tenaga profesional yang bertugas merencanakan dan melaksanakan proses pembelajaran, menilai hasil pembelajaran, melakukan pembimbingan dan pelatihan, serta melakukan penelitian dan pengabdian kepada masyarakat, terutama bagi pendidik pada perguruan tinggi”.

Secara garis besar Undang-Undang Guru dan Dosen ini terdiri dari VIII bab dan 84 pasal. Namun, tidak semua isi bab-bab dalam undang-undang ini akan didiskripsikan, melainkan hanya beberapa substansi yang berkaitan dengan dosen yang menjadi fokus dalam penelitian ini.

\section{Kesimpulan}

${ }^{15}$ Ibid.,hlm. 20.

Suloh: Jurnal Fakultas Hukum Universitas Malikussaleh, Vol. 7, No. 2, April 2019, pp. 35-47 
Berdasarkan penjelasan pada bab sebelumnya dapat disimpulkan bahwa terjadinya perbedaan norma hukum antara Undang-undang Guru dan Dosen dengan Undang-undang ASN dalam pengaturan disiplin PNS dikarenakan bahwa tujuan pembentukan Undang-undang Guru dan Dosen adalah untuk peningkatan mutu guru dan dosen sebagai profesi yang bermartabat. Tujuan pembentukan Undang-undang ASN adalah sebagai payung hukum bagi PNS yang telah memiliki berprofesi seperti guru, dosen, jaksa, hakim dan dokter.

\section{DAFTAR PUSTAKA}

Akhmad Aulawi, Penerapan Sistem Merit dalam Manajeman ASN dan Netralitas ASN dari Unsur Politik Dalam Undang-Undang ASN, (Jurnal Rechvinding Online)

A. Rasyid Al Atok, Konsep Pembentukan Peraturan Perundang-Undangan, Edisi Revisi, (Malang: Setara Press, 2015)

HenyYuningrum, Dampak Ekonomi dari Penerapan Sistem Biometrik di Kalangan PNS Perguruan Tinggi Islam, (Jurnal Economica, Volume V Edisi 1 Mei 2014)

Indonesia, Undang-Undang Guru dan Dosen, UNDANG-UNDANG Nomor 14 Tahun 2005, LN No. 157, TLN No. 4586

Indonesia, Undang-Undang Pembentukan Undang-Undang, Undang-Undang Nomor 12 Tahun 2011, LN. 82, TLN No. 5234.

Indonesia, Undang-Undang Aparatur Sipil Negara, Undang-Undang Nomor 5 Tahun 2014, LN No. 6, TLN No. 5494

Indonesia, Peraturan Pemerintah tentang Dosen, PP Nomor 37 Tahun 2009 LN No. 76, TLN No. 5007

Indonesia, Peraturan Pemerintah tentang Disiplin Pegawai Negeri Sipil, PP Nomor 53 Tahun 2010 LN No. 74, TLN No. 5135

Kusnu Goesnadhie S, Harmonisasi Sistem Hukum: Mewujudkan Tata Pemerintahan yang Baik, (Malang: Nasa Media, 2010)

-------, Harmonisasi Hukum dalam Perspektif Perundang-Undangan, (Jurnal Hukum Vol. 27, tanggal 11 Sepember 2004)

Peter Mahmud Marzuki, Penelitian Hukum, (Jakarta: Prenamedia Group, 2015)

Risalah DPR-RI, Rancangan Undang-Undang Guru dan Dosen, Tanggal 6 Desember 2015

Satjipto Raharjo, Ilmu Hukum, Cetakan Keenam, (Bandang: PT. Citra Aditya Bakti, 2006).

Syahir Badruddin, Efektivitas Pelaksanaan Fingerprint di IAIN Raden Patah Palembang, Jurnal Wardah No. XXVII Juni 2014.

Yuliandri, Asas-Asas Pembentukan Peraturan Perundang-Undangan Yang Baik: Gagasan Pembentuk Undang-Undang Berkelanjutan, (Jakarta: PT Raja Grafindo Persada, 2013) 